\title{
Learning from the Corona Virus Pandemic: Interdisciplinary History and Strategic Issues of Historical Research
}

\author{
Bambang Purwanto \\ Department of History, Faculty of Humanities, Universitas Gadjah Mada, \\ Yogyakarta, Indonesia \\ *Corresponding Author: purwantougm@yahoo.co.uk \\ DOI: https://doi.org/10.14710/ihis.v4i2.9240
}

\begin{abstract}
Received:

October 22, 2020

This paper discusses the function of history as a science that can be used to formulate strategies to face various challenges as well as present and future opportunities based on knowledge, understanding, and their meaning of the past.

Revised: Responding to the present worldwide Covid-19 pandemic, this paper aims to

December 6, 2020 build awareness among historians to strategic issues by learning from the history of diseases through interdisciplinary historical research. The existence of adequate

Accepted: knowledge and understanding of the past of the aforementioned issues will

December 6, 2020 provide space for history as a science to make contributions that can be used as a policy, in which history is a science for thinking forward through the past.
\end{abstract}

Keywords: History; Interdisciplinary; Pandemic; Policy; Research; Strategic.

\section{Introduction}

Michael B.A. Oldstone in a chapter of his book entitled Viruses, Plagues, and History. Past, Present, and Future, published in 2010, predicts the influenza virus that will again threaten the lives of mankind around the world in the future. After major cases of disease outbreaks that threatened mankind such as the Spanish flu pandemic at the end of the second decade of the 20th century, followed by the H5N1 bird flu epidemic at the end of the 20th century, and the SARS-CoV coronavirus pandemic at the beginning of the century $21^{\text {st }}$. Oldstone, who spent most of his career as an immunologist, microbiologist and inflammation expert in California, the United States of America and has written and edited both historical books and medical books on infectious diseases, through his disease historical studies, is very confident that sooner or later new plague will again pose a major challenge to sustainable health quality around the world.

Oldstone, who has been elected a member of the National Academy of Sciences in the United States since 2008, has come to a much different conclusion compared to other opinions that have ever existed, especially in the large historiographical tradition which is so dominated by political history. For Oldstone, the importance and greatness of the course of human history is not in victory in war, nor the formation of dynasties, and also not because of the success in building financial capacity, but depends on improving conditions in mankind itself (Oldstone, 2010, p. 342). Furthermore, together 
with Richard W. Compans, they edited a volume of the book series entitled Influenza Pathogenesis and Control, concluded that the ability to get rid of disease is the key to the success of a civilization, and those who participate in the process are the real actors of the new world or in the medical imagination, having antibodies that can build a sustainable immune system to fight any disease is the main determining factor for the continuity of human history (Compans \& Oldstone, 2014). A historical perspective that is oriented towards the future, and places the sustainable quality of human living conditions itself as a central point in the process of history.

If Oldstone's opinion is put in a contemporary context, to some extent it will relate to the premise of UNESCO's big concept "Our Common Future" document, where the sustainable element is the main element for any strategic steps that impact human life in the future. As a field of science that focuses on discussing the past of mankind, history certainly cannot be separated from its responsibility to contribute to human life sustainably. The existence of this future orientation is consciously understood not to contradict the utopian or eschatological way of thinking, considering that one of the important elements of history is a reality framed by a clear space and time. Referring to the four possible ways of thinking and feeling developed by Arnold Toynbee, namely archaism, futurism, escapism, and transfiguration, a history that is oriented towards the future will equip mankind to avoid selfdestruction without neglecting the interference of nature and destiny. At this level, history as science also does not want to be opposed to what Georges Sorel called "social myth" or even utopia itself (Polak, 1973).

This paper discusses the function of history as a science that can be used to formulate strategies to face various challenges as well as present and future opportunities based on knowledge, understanding, and their meaning of the past. Other sciences can use knowledge of the past to formulate policies, planning, or thinking models, as did by William Strauss and Neil Howe. The two political consultants categorized generations in human history based on their birth date, namely lost generation, G. I. generation, silent generation, boom generation, thirteen generations, and the millennial generation. So, it would be very ironic if historians only dwell on the description of the past, or make history merely as a documentation of what has happened, without any relevance to the present and future life. Compared to other scientists, historians have the most complete scientific tools to present facts from the past and their historiographical constructs.

\section{Research with Impacting Strategic Issues}

The Oldstone's unconventional conclusion as mentioned above, of course, becomes a challenge and at the same time an opportunity for historians who study the past. Reflecting on someone like Oldstone, who throughout his professional career has been in the field of medical research but has been able to produce historical constructs that are very useful for the present and the future, historians should start to think that strategic issues in historical research no longer refer to themes and functions of history conventionally, as has been done so far, which only relies on the state, politics, and 
power. Instead, other themes that have relevance to prepare a good condition for the quality of human beings as stated by Oldstone in the study of disease history, need attention.

History should not continue to work solely on issues of national ideology, showing greatness, superiority, or majesty because of victories that have been achieved, economic successes and failures, or to obtain normative values that can guide oneself to be wiser. The results of historical research should also be placed as part of the ability to create real conditions in human life, both as individuals and groups, by always thinking forward through their past. Or in other words, historical research must also be able to present the "impact" of each construction, interpretation, and explanation of the past produced (Berridge, 2018).

Reflecting on the work of Michael B.A. Oldstone, an article that discusses the strategic role of history as a relevant science and can make a meaningful contribution to this sustainable present, aims to ensure a future. Therefore, the society in which this historical process occurs can build awareness and at the same time be responsible for the future it will live in, not only by itself and the period when it has been historical but also for the next generation. In this context, the past, present, and future are seen as a single narrative that interacts and forms one another.

Referring to Kuntowijoyo's opinion, history as historiography is not an antiquarian that dwells on the past. History as historiography should have a function as social criticism, where historical reconstructions have the task of understanding the present and predicting the future (Kuntowijoyo, 2000, p. 83). Furthermore, according to Kuntowijoyo, this historiography that demands high academic standards will certainly not function as political pamphlets, as has often been the case in most historical works so far. Hence, questions such as why policy requires history and historians (Berridge, 2018), or why Indonesia needs history (Purwanto, 2020), is increasingly relevant to be questioned in the context of understanding the function of history as suggested by Kuntowijoyo.

Of course, it is not the aim of this paper to further discuss the two questions above, but rather to build awareness among historians to research strategic themes. So, it will place history as a science that has real relevance to challenges and opportunities that exists in the present and the future. Therefore, historical research is no longer seen only as part of a study filled with elements of philosophical idealism, or just an illusion or fictional imagination that does not set foot on the reality of everyday human life. Like facts as a reality which becomes the basic material of any historical study, history as a science should be able to present itself with real relevance as well.

That principle at the same time will also ward off the opinion of some people that history as a science is not equipped with methodological tools and theories. Whereas historical scientific work is to find facts from the traces left by the past to synthesize them into a unified story in a chronological and coherent timeline, not only complemented by methods but also methodology together with philosophy and historical theory and its epistemology (Kartodirdjo, 1992; Kuntowijoyo, 1994; Lorenz, 
2011). It is just that in the context of the theory according to Chris Lorenz, most historians never realize that they always ask theoretical questions but without realizing it (Lorenz, 2011, p. 14).

At this time when the COVID-19 pandemic is rampant and haunting all aspects of human life, one of the challenges and opportunities is in the study of disease history, health history, and other related themes as an interdisciplinary study. In this context, a construction about the past is built on the base of knowledge, methods, theories, and methodologies from various disciplines which are integrated as a single unit (Van den Basselar \& Heimeriks, 2001; Aboelela et al., 2007). The complexity and multi-faceted nature of the realities and social phenomena of a pandemic require interdisciplinary studies to be able to explain and understand the events that occurred to find a holistic solution to the problems it caused and determine the necessary future steps (Razzaq et al., 2013, p. 151).

This is also done at the same time to differentiate themselves from multidisciplinary studies, where those who come from different disciplines work together to discuss the same issue, but everyone works with their respective scientific tools. Although it is not easy to distinguish from one another, this interdisciplinary study to some extent also needs to be distinguished from the transdisciplinary tradition, where experts from different disciplines place more emphasis on forming a whole new way of thinking outside of the scientific tools of each discipline to understand and explain the complexity of one particular aspect (Van den Basselar \& Heimeriks, 2001; Aboelela et al., 2007). In this context, transdisciplinary refers to crossdisciplinary, interdisciplinary, and beyond or outside the discipline, so that crosspollination between ideas is created while respecting the working principles of each discipline (McGregor, 2004).

\section{Interdisciplinary Disease History and Future Prediction}

The existence of influenza as a disease caused by a virus is not something new in human history. A disease accompanied by fever, cough, and sneeze that often complicates pneumonia has haunted people in many countries around the world for centuries. One of the earliest records of an influenza pandemic dates back to 1580 when an influenza outbreak originating in Asia spread to various regions in Europe, Africa, and America following trade routes at that time (Tognotti, 2009, p. 331).

One of the well-known influenza outbreaks was the Spanish flu epidemic at the end of the second decade of the 20th century, which spread not only in the European continent but also to America, Africa, and Asia, including Indonesia, which at that time had the status of a Dutch colony. In Spain alone, the influenza virus epidemic has killed at least 170,000 people. An article by Warren T. Vaughan published in the American Journal of Epidemiology in 1921 as cited by Michael B.A. Oldstone stated that at the time of the outbreak, influenza killed no less than $1.9 \%$ of the total population in an area in just one month (Oldstone, 2010, p. 309). Meanwhile, other data suggest that the death rate from the Spanish flu is as high as $2.5 \%$, compared to the less than $0.1 \%$ caused by previous influenza epidemics. In India, statistics show that 
there are 50 deaths out of 1000 infected, while in the Philippines the mortality rate is 2.8\% (Tognotti, 2009, p. 331).

In Indonesia, the death rate from the Spanish flu varies widely, depending on the region. The Dutch East Indies government tended to reduce the number of deaths or even cover up the actual events. Even though a report on Saparua, out of 800 people there were only 8 people who were able to work at the peak when this outbreak attacked the Maluku islands. This shows that the Spanish flu has had a significant impact on this area. Almost the same incident also happened to tin mining workers in Belitung, from about 10,000 workers there were no less than 2600 people who had been infected with the Spanish flu (Chandra, 2013, p. 187).

In some areas, the mortality rate reaches an average of $10 \%$ of the total population, but in certain areas, it reaches no less than $16 \%$. Therefore, some experts state that no less than 1.5 million people died because of the Spanish flu pandemic in Indonesia at that time (Brown, 1985, pp. 238-239), while others argue that the number of deaths is as high as 2.5 million, or $5 \%$ of the total world death toll of 50 million (Chandra, 2013, p. 191). Even this mortality rate is expected to be much higher if the mortality rate in some areas outside the main islands is also included in the calculation.

Meanwhile, referring to the death rate on Java Island during 1915-1920, when the second wave of the Spanish flu hit the region towards the end of 1918, the death rate in East Java increased sharply compared to the previous two years. The same thing happened in West Java and Central Java, although it was still below the death rate in East Java (Ravando, 2020, p. 169). In Jakarta, every day no less than 6 Europeans and more than 150 indigenous people die. Doctor deaths caused by the Spanish flu also occurred, as experienced by a doctor at a military hospital in Jakarta. Meanwhile, almost all existing hospitals are unable to accommodate the number of patients that have increased drastically, so they must be treated without adequate facilities (Ravando, 2020, p. 193).

The condition was exacerbated by the spread of various confusing news both in the mass media and amid society, and the attitudes and statements of some colonial officials who underestimated the impact of the outbreak. As a result, panic and fear engulfed society as a whole indiscriminately, both among the indigenous and Chinese as well as the European population (Ravando, 2020, p. 193). The condition was exacerbated by the spread of various confusing news both in the mass media and amid society, and the attitudes and statements of some colonial officials who underestimated the impact of the outbreak. As a result, panic and fear engulfed society as a whole indiscriminately, both among the indigenous and Chinese as well as the European population.

The panic and fear of the influenza epidemic that hit people around the world at that time can be seen on a poster put up by a theater in the city of Chicago, the United States between 1918-1920. On posters plastered across the city and advertisements for local newspapers, contained a message as well as a warning "if you have a cold and are coughing and sneezing, do not enter enter this theatre, go home and go to bed until you are well; coughing, sneezing or spitting will not be permitted in the theatre, 
in case you must cough or sneeze do so in your own handkerchief, and if the coughing and sneezing persists leave the theatre at once" (Oldstone, 2010, p.310). Meanwhile, from the photo showing police officers on duty and soldiers parading in the United States at the same time, wearing masks has become one way to prevent contracting the deadly disease. Schoolchildren in Japan have done a similar thing, where photos from the same period show children wearing masks when going to school (Ravando, 2020).

Influenza epidemics came and went on a smaller scale throughout the 20th century, following the 1918-1919 Spanish flu pandemic. In 1933, for example, the influenza epidemic hit London once again. This incident opened a new puzzle when a staff member of the health research center caught influenza after an experimental ferret sneezed and hit his face. The incident raises questions about the transmission of influenza from animals to humans, not only from human to human as previously believed. Although the suspicion about a link between influenza that occurs in humans also occurs in animals, it is not something new.

When the influenza epidemic hit the United States in 1918, a supervisor at the veterinary institute had expressed suspicion that the pigs he examined had influenza, but he had not found further strong evidence to link it to influenza affecting humans. Meanwhile, although the first evidence that a virus causes the transmission of influenza in pigs was believed to be in 1928, it was only after the events that occurred in London that researchers firmly believed that viruses were the cause of influenza in humans. (Oldstone, 2010, p. 317), which then prompted further steps to find a vaccine for influenza in humans.

In subsequent developments, most experts are optimistic that neither the H5NI and H9N2 avian flu viruses nor the swine flu (H1N1) and Russian flu (H1N1) that contracted from animals to humans in the late 20th century would not spread from person to person on a scale that massive, after finding evidence that the mutation and malignancy of the virus continue to weaken when dealing with antibodies in the human body. The discovery of Tamiflu, which is commonly used to treat bird flu sufferers, for example, gives a greater sense of optimism. Even so, in reality, the death rate from the disease, also known as avian flu, was $63 \%$ of the 373 confirmed cases. According to WHO data for 2008, Indonesia occupies the first place in the number of cases of confirmed bird flu deaths, namely 129 cases with 105 deaths (Oldstone, 2010, p. 325).

The same optimism was formed when the SARS-CoV outbreak hit the world at the beginning of the 21st century. Even though from the beginning when it was identified in 1930, the disease caused by the coronavirus which disturbs the respiratory system and results in difficulty for sufferers to absorb oxygen, is known as a deadly disease. However, experts feel that they have isolated it from humans since 1960. So it was categorized as a disease that causes only minimal mortality. Concerns arose when the coronavirus became epidemic again at the end of 2002. Based on confirmed data, the disease caused by the virus in the corona family has indeed attacked more than 8,000 people in more than 30 countries and on five continents, with the victim died. as 
many as more than 700 people. However, experts later believed that a more massive spread of this disease had been contained in 2004 .

In contrast to most experts who only rely on research data in various available statistical data laboratories, Michael B.A. Oldstone, who has historical knowledge and understanding, is always suspicious of the current phenomenon of every outbreak that occurs. While some experts feel optimistic that they can control the SARS-CoV epidemic so that it does not become a pandemic that threatens mankind around the world. Oldstone wraps the phenomenon with sarcastic diction in its historical narrative, as "beginning mysteriously in Southern China ... and then as mysteriously as it came, it disappeared" (Oldstone, 2010, p. 226). From that statement, it can be estimated that up to the time he finished writing his book, Oldstone still left big questions related to the phenomena that occurred with bird flu at the end of the last century and SARS-CoV at the beginning of this century.

The curiosity that grows in Oldstone can also be linked to his opinion that is framed by knowledge and understanding of history when addressing various policies to tackle the wider spread of the plague. For every step taken by all parties to be effective and able to prevent an outbreak such as the Spanish flu pandemic in 1918 from occurring again, Oldstone suggested "... a sophisticated and well-organized global network" (Oldstone, 2010, p. 324). However, he is very aware that this is not something easy to realize considering there are various political and structural constraints both at the international level and in each country or region.

Meanwhile, to maintain a sense of optimism, at the same time Oldstone also sees the recent existence of several new variants of the influenza virus and the return of the influenza virus which has long been known, as a challenge and at the same time areat opportunity in the future for microbial hunters. Different from the pessimism expressed by Paul de Kruif, the author of the very famous book Microbe Hunter and being an inspiration for himself to study the history of the disease, Oldstone strongly believes that these microbial hunters will succeed in finding an effective vaccine capable of controlling diseases caused so as not to become an epidemic that threatens the lives of mankind around the world, as has been done by its predecessors who invented vaccines to control smallpox, polio, measles, or yellow fever.

It turns out that Michael B.A. Oldstone did not have to wait so long, his predictions came true soon. At the end of 2019 or just ten years after he wrote the preface to the last edition of his book, the world began to face an outbreak of a new variant of the coronavirus which became known as COVID-19. The disease, which started as an epidemic in China, has rapidly developed into a pandemic that has hit almost the entire world, including Indonesia. As has happened in pandemics in the past, panic has occurred in almost all levels of society and the country. The availability of various latest technological tools ranging from medicine and pharmacy to information that has far exceeded the limits that existed when a pandemic occurred before, still unable to give everyone a sense of security.

According to data released by $\mathrm{WHO}$ and other credible data centers as of September 27, 2020, this outbreak has infected people in 215 countries. The number of 
those exposed has reached more than 30 million people, where the death toll is close to 1 million, while more than 24 million people have been cured (www.covid19.who.int and www.worldometers.info/coronavirus). Even though WHO has announced that several vaccines being researched has passed clinical trials, and several countries and companies have stated that their scientists have succeeded in developing a vaccine for COVID-19, it can be said that at the time of this writing the availability effective vaccine for mass immunization purposes and to tackle the spread of the COVID-19 outbreak is still a serious problem in many countries.

As happened when the Spanish flu hit the world in the first two decades of the 20th century, masks have also become an important part of the daily lives of people around the world so they will not be affected by the current COVID-19 outbreak. In Indonesia, the price of masks has jumped by more than $500 \%$ from pre-pandemic prices without the ability and willingness of the government to control it (www.liputan6.com, Maret 4, 2020; https://www.balipuspanews.com/dampak-viruscorona-harga-masker-naik-600-persen.html). The law of a capitalistic market economy works well, where the price increase follows the demand, not the purchasing power of society. When the supply of masks has been controlled, prices remain high because market demand is still high, even after more than 6 months since COVID-19 was first officially recognized by the Indonesian government for its existence in Indonesia (www. economy.okezone.com. 2020/09/21; www. telisik.id/news/harga-maskermahal-tak-pakai-masker-didenda, 5 Sept. 2020).

Michael B.A. Oldstone has pointed out that history is a strategic science when oriented to the present and the future. When interdisciplinary research that combines history with immunology, microbiology, and epidemiology is used to write history of disease, comprehensive and in-depth knowledge and understanding of outbreaks is presented. History no longer exists as a construction of a collection of facts from the past that is surprising and astonishing, but rather a representation of a series of facts from the past framed by an attitude of optimism for the present and the future. As a saying put it, only optimists have the future. Even though both philosophically and sociologically there are limitations and failures of optimism as stated by Robert L. Heilbroner (Heilbroner, 1961, p. 179-184), historical studies framed by optimism can give present and future nuances to the studies carried out. Or in other words, understanding the relationship between the past, present, and future is believed to be able to form a much more comprehensive and holistic understanding of the world around us that is now facing the COVID-19 pandemic and other health challenges.

\section{History as the Future}

The idea of history as the future is endorsed by the United Kingdom's Art and Humanities Research Council, who promotes "new novel understandings of the relationship between the past and the future, and the challenges and opportunities of the present through a temporally-inflected lens". Presented with the principle of "Care for the Future", this institution invites people from various backgrounds to "Thinking Forward Through the Past" ("Arts \& Humanities Research Council," n.d.). The 
principle "will encourage critical reflection upon the concepts that are used to join past, present and future." together. The Arts \& Humanities Research Council then develops and promotes historical research that is collaborative multidisciplinary, transdisciplinary, and the main one is interdisciplinary, which includes not only researchers or academics but also creative and professional culture workers.

In the context of Indonesian history, the way of thinking ahead by utilizing history to build strategic steps is not truly new. Hamengkubuwono II, before becoming the ruler of the Yogyakarta Sultanate, had done this to continue Hamengkubuwono I's idea of reuniting the Mataram Kingdom in the future, based on historical essence. Raja Ali Haji did the same thing in the 19th century. This Gurindam writer plans strategic steps for the future modernization of Malay society and culture that refers to its past, without having to experience isolation in the socio-cultural space that has changed at that time, and is predicted to continue to change in the future (Purwanto, 2006). Therefore, when history was understood as prophecy in the Javanese historical tradition, Nancy Florida concluded that for the Javanese "writing the past inscribing the future" (Florida, 2003).

Making predictions, of course, is not the same as fortune-telling, and history as a science is learned not to tell fortunes. History is the science of the past, there is no history without facts which are evidence of the existence of the past. In this context, it can be said that history is not a science of the present and the future, but by placing the variables of relevance and orientation of the present and the future in historical studies, history becomes a science for thinking forward through the past. Past events that become the object of historical research, are transformed into subjects as well as methodological tools for present understanding and predicting the future.

Responding to the predictions of virologists and public health that a large-scale influenza pandemic will occur again in the 21st century, Eugenea Tognotti (2009, p.334) also referred to the book The Threat of Pandemic Influenza: Are We Ready? published in 2005 states, "the lessons of the past can be of crucial importance in planning effective control in case a pandemic with the magnitude on that in scale as 1918 occurs again". Just like Michael B.A. Oldstone, Tognotti also put historical knowledge and understanding as a powerful predictor and frame of thought to formulate policies.

Attempts to link history with a policy in the historical context as a future are not as easy as imagined. George Orwell's quotation that "whocontrols the past controls the future: who controls the present controls the past" has always been understood in the context of the political domination and power of a regime rather than the mentality and public intellectual discourses. In a society where capitalism is supported by liberal political thought and neo-classical economics is so dominant, one of the frameworks often presented regarding contemporary phenomena such as COVID-19 is a conspiracy theory.

The power of capital and efforts to establish political domination is often assumed to be the driving force for the dominant power to fabricate reality for its interests and at the same time to overthrow its rivals. Amid global poverty, resource 
constraints, and the current wide gap between the First World group and the rest of the world, China's ambitions in competition with the United States and Russia are the focus of conspiracy theories. Therefore, the existence of the COVID-19 virus outbreak is assumed to be part of a complex and multi-layered alliance, which includes various elements to uphold certain supremacy.

For China, the assumptions that have been believed to be true by some groups are difficult to deny. This is related to the fact that the spread of the COVID-19 virus throughout the world began with an epidemic in China, which then transformed into a pandemic that hit almost the entire world. Whereas from the history of disease it is known that, like what applies to the United States, China has always been in a central position in every endemic, epidemic, and pandemic that occurs, long ago when China was not yet a superpower and was even still space for the struggle for various Eastern and Western powers in the past. A very large population, and a very wide area coverage makes China seem to represent the world itself and its various problems. Whereas if conspiracy theories are used as a basis for thinking to explain current phenomena and realities, it will close the space for historical relevance to understanding everyday life and the function of prophecy to design the future.

Referring to the framework of thinking about caring for the future by thinking ahead through the past developed by the United Kingdom's Art and Humanities Research Council, the results of historical research are in principle a warning that comes from the past in the present space which serves to ensure future conditions. In this context, it is also necessary to ensure that history as historiography which is presented is not trapped in the idealism and romanticism of the past because of unhappiness toward the present conditions. Through this way of thinking, the past, present, and future must function equally.

Since time is a major element in the science of history, when it is stated that "...the structure of time intersects with and inform our sense of ourselves in myriad way..." ("Arts \& Humanities Research Council," n.d.) then the future is no longer just a fictional imagination, but a series of predictive conceptualizations as a continuation of the realities that exist in the past and present. In this context, comprehensive knowledge and understanding of the past can become the basis for determining the types of policies that are planned and implemented to have a sustainable impact. It is at this level that historical research can show the impact of the resulting historical construction. While other subsequent tasks are the responsibility of other scientists, together with practitioners, bureaucrats, and of course society as a whole.

\section{Conclusion}

One question that continues to be raging for everyone around the world, including in Indonesia, is when will the abnormalities caused by the COVID-19 pandemic end? In an attempt to answer a similar question, some statisticians and epidemiologists have submitted their predictions of the mid-and late-year deadline as peaks, and then continue to slope and eventually return to normal. In Indonesia, there are even politicians who talk about the COVID-19 outbreak which will end in April or the 
summer of this year. However, mid-2020 has passed and in various parts of Indonesia, it has entered the rainy season, while the plague continues to hit and has not even shown any signs of abating soon. The situation was getting worse and worse and seemed out of control. Therefore, those who are pessimistic, then think about the new normal that will occur in the next two years.

It was this uncertainty that led to the emergence of the slogan "the new normal," a false state formed based on inspiration drawn from the fictional imagination of electronic games. The slogan which was then responded to as euphoria but clad in fear, the real situation was never real. The rationality of thinking of even the most rational of them has been shattered to understand the reality of everyday life because there are no sufficient references to ensure a picture of the future. If you want to refer to history, there is not a single pandemic that has occurred in the past which only had an impact of less than one year to achieve normalcy. Some of them even took more than five years.

When public rationality has been lost and state policies are not equipped with adequate historical knowledge and understanding, it can be imagined how long it will take the Indonesian people to return to normal conditions as before. When the Spanish flu epidemic hit Indonesia at the end of the second decade of the twentieth century, the "colonial assertiveness" that usually appears historiographical as "the arbitrariness of colonial power" succeeded in limiting irrational public actions that could spread the disease. It is ironic that when Indonesia has the status of an independent nation-state, the country is almost helpless in the face of public irrational actions, such as the forcible removal of bodies exposed to the COVID-19 virus for various reasons. In fact, this kind of action has proven to be one of the causes of the increase in the number of cases and the geographic expansion of those exposed to COVID-19 in Indonesia.

All of these are challenges and opportunities for historians to develop a historical research agenda that has strategic content. Apart from disease history or health history, several historical research agendas that will have an impact on policy need to be considered together. Some of the agendas that can be included in the list of strategic research include the history of healthy food, the history of daily life in a healthy lifestyle, a mental history or psychological history related to epidemics, cultural history related to health and disease, history of sports health, or drug history and their consumption. The existence of adequate knowledge and understanding of the past of the aforementioned issues will provide space for history as a science to make contributions that can be used as a policy. History as science is of course not an element that will determine when the COVID-19 pandemic will end. However, the work of historians is a form of concern for a better present and future sustainably, so that they can formulate strategic steps to overcome the COVID-19 pandemic in Indonesia. This is also a preventive measure to prepare for future pandemics, from which a broad impact and multidimensional crises could be avoided. 


\section{References}

Aboelela, S. W., Larson, E., Bakken, S., Carrasquillo, O., Formicola, A., Glied, S.A., Haas, J., \& Gebbie K. M. (2007). Defining interdisciplinary research: Conclusions from a critical review of the literature. Health Services Research, 42 (1), 329-346. https://doi.org/10.1111/j.1475-6773.2006.00621.x

Arts \& Humanities Research Council (n.d.) Care for the future: Thinking forward through the past. Retrieved September 19, 2020, from https://ahrc.ukri.org /documents/projects-programmes-and-initiatives/care-for-the-future-thinkingforward-through-the-past/.

Banyak Negara Kena Corona, di RI Harga Masker Naik 5X Lipat (February 27, 2020)

Retrieved from www.cnbcindonesia.com/news/20200227204636-4-

141009/banyak-negara-kena-corona-di-ri-harga-masker-naik-5x-lipat

Berridge, V. (2018). Why policy needs history (and historians). Health Economics, Policy and Law, 13 (3-4), 369-381. https://doi.org/10.1017/S1744133117000433

Brown, C. (1987). The influenza pandemic of 1918 in Indonesia. In N. G. Owen (ed.) Death and disease in Southeast Asia. Singapore: Oxford University Press (pp. 235256).

Chandra, S. (2013). Mortality from the influenza pandemic of 1918-19 in Indonesia. Population Studies, 67 (2), 185-193. https://dx.doi.org/10.1080\%2F00324728.2012.754486

Compans, R. W. \& Oldstone, M. B. A. (2014). Influenza pathogenesis and control volume I. [Springer International Publishing]. doi 10.1007/978-3-319-11155-1

Dampak virus corona harga masker naik 600 persen (March 3, 2020). Bali Puspa News. Retrieved from https://www.balipuspanews.com/dampak-virus-corona-hargamasker-naik-600-persen.html.

Florida, N. (2003). Menyurat yang silam menggurat yang menjelang. Sejarah sebagai nubuat di Jawa masa kolonial. Yogyakarta: Bentang Budaya.

Harga Masker Mahal, Tak Pakai Masker Didenda (September 5, 2020). Retrieved from www.telisik.id/news/harga-masker-mahal-tak-pakai-masker-didenda.

Heilbroner, R. L. (1961). The future as history. New York: Grove Press.

Kartodirdjo, S. (1992). Pendekatan ilmu sosial dalam metodologi sejarah. Jakarta: Gramedia Pustaka Utama.

Kuntowijoyo (1994). Metodologi sejarah. Yogyakarta: Tiara Wacana.

Kuntowijoyo (2000). Indonesian historiography insearch of identity. Humaniora, 12 (1), pp. 79-85.

Lorenz, C. (2011). History and theory. In The oxford history and historical writing, Vol. 5: Historical writing since 1945. Oxford: Oxford University Press, pp. 13-36

McGregor, S. L. T., The nature of transdisciplinary research and practice. Retrieved from www.researchgate.net/publication/238606943.

Oldstone, M. B. A. (2010). Viruses, plagues, and history. Past, present, and future. New York: Oxford University Press.

Polak, F. (1973). The image of the Future. Amsterdam: Elsevier Scientific Publication Company.

Purwanto, B. (2006). Gagalnya historiografi indonesiasentris?!. Yogyakarta: Ombak. 
Purwanto, B. (2020). Mengapa Indonesia memerlukan ilmu sejarah? Beberapa gagasan untuk "hilirisasi" historiografi. Bakti Budaya, 3 (1), 4-19. https://doi.org/10.22146/bb.55495

Ravando (2020). Perang melawan influenza. Pandemi flu spanyol di Indonesia masa kolonial, 1918-1919. Jakarta: Kompas.

Razzaq, J. Townsend, T., \& Pisapia, J. (2013). Towards an understanding of interdisciplinarity: The case of a British university. Issues in Interdisciplinary Studies, 31, 149-173. http://hdl.handle.net/10323/4484

Tognotti, E. Influenza pandemics: A historical retrospect. The Journal of Infection in Developing Countries, 3 (5), 331-334. https://doi.org/10.3855/jidc.239

Van den Basselar, P. \& Heimeriks, G. (2001) Disciplinary, multidisciplinary, interdisciplinary-concept and indicators. Proceedings 8th international conference on scientometrics and informetrics. Sydney: University of New South Wales. 